\title{
Assessment of Wastewater Management and Health Impacts in African Secondary Cities: Case of Dimbokro (Côte D'Ivoire)
}

\author{
Sandotin Lassina Coulibaly ${ }^{*}$, Drissa Sangaré1, Sylvain Kouakou Akpo' ${ }^{1}$, Seydou Coulibaly², \\ Habib Ben Bamba ${ }^{2}$, Lacina Coulibaly ${ }^{1}$ \\ ${ }^{1}$ Unité de recherche en Biotechnologie et Ingénierie de l’Environnement, Université Nangui Abrogoua, Abidjan, \\ Côte D'Ivoire \\ ${ }^{2}$ Service Hydraulique et Assainissement, TERRABO Ingénieur Conseil, Abidjan, Côte D'Ivoire \\ Email: ‘sandotinc@gmail.com,dsangare2012@gmail.com,sylvain.akpo@yahoo.fr, \\ sedou.coulibaly@terrabo.com,habib.bamba@terrabo.com,coulacina2003@yahoo.fr
}

Received 10 June 2016; accepted 1 August 2016; published 5 August 2016

Copyright (C) 2016 by authors and Scientific Research Publishing Inc.

This work is licensed under the Creative Commons Attribution International License (CC BY). http://creativecommons.org/licenses/by/4.0/

(c) (7) Open Access

\section{Abstract}

The majority of population growth in developing countries will occur in secondary cities where there is limited access to clean water and sanitation. Wastewater management priorities in these cities will be different from those in larger cities and developed countries. For this reason, it is important to assess wastewater management in these cities of sub-Saharan Africa. This study assessed clean water supply, wastewater and faecal sludge management and associated health risks in Dimbokro, Côte D'Ivoire. The study was performed in March 2015 in 12 neighborhoods with a total of 703 households. In these neighborhoods, the questions were addressed and discussed with household head. The study revealed that the households of the city were structured on three topology habitats: residential (5\%), economic (42\%) and evolutive or yards housing (53\%). For water supply, $\mathbf{9 9 . 4 \%}$ of the households used water from SODECI, the local public water supply network, while the remaining $0.6 \%$ of surveyed household obtained water from wells. Domestic wastewater, used for doing laundry, dishwashing and showering, was disposed of in the following ways: directly into the street (33\%), septic tank (23\%), backyards $(18 \%)$, storm drain (16\%), sewer network $(6 \%)$, pit latrine $(3 \%)$ or into soakaway $(2 \%)$. In addition, untreated wastewater was sometimes discharged into the N'Ziriver by certain households. $52 \%$ of households surveyed emptied latrines manually and $48 \%$ used mechanic drain services. The most frequent diseases occurring in the households were Malaria (63\%), Diarrhoea (13\%) and Typhoid fever (9\%) in the households of the city. In the light of this study, the municipal authorities of Dimbokro should provide the city with wastewater systems that drain to a central outlet system where the wastewater can be easily treated before final disposal for reuse in agriculture.

"Corresponding author.

How to cite this paper: Coulibaly, S.L., Sangaré, D., Akpo, S.K., Coulibaly, S., Bamba, H.B. and Coulibaly, L. (2016) Assessment of Wastewater Management and Health Impacts in African Secondary Cities: Case of Dimbokro (Côte D'lvoire). Journal of Geoscience and Environment Protection, 4, 15-25 http://dx.doi.org/10.4236/gep.2016.48002 


\section{Keywords}

\section{Diseases, Households, Faecal Sludge, N'Zi River, Secondary Cities, Wastewater}

\section{Introduction}

Most diseases in developing countries are caused by lack of clean water and sanitation. In 35 developing countries worldwide, 26 of which are in sub-Saharan Africa, and coverage of improved drinking water supply is between 50\% and 75\% [1]. Even if several significant efforts in terms of access to drinking water are noticed, the issue of sanitation remains a major challenge in developing countries. Poor wastewater management coupled with a lack of sanitation facilities has aggravated the sanitation challenges in cities of developing countries [2] [3]. Most of the population in these cities does not have access to safe and adequate water supplies and sanitation facilities. In most major cities, if wastewater is not collected by individual systems, it is discharged without treatment into the street or into public storm water drains, causing contamination of water bodies and health risks [4]. Poor sanitation is one of the most important contributors to morbidity and mortality in the world [5]. In fact, ill health associated with inadequate water supply and sanitation facilities is one of the most significant concerns in many developing countries [6]. Moreover, the lack of appropriate sanitation (and related water and hygiene) is both a cause and effect of the vicious poverty cycle in which millions of people are trapped [7]. The sanitation problem is more accentuated in secondary cities, because governments prioritize major cities, which are often also the seat of government. Secondary cities have not attracted as much economic activity, nor have they exhibited much internal dynamism in terms of management. There is a clear disparity between the public services received by the towns or cities, depending on their economic strata. The majority of African secondary cities have no sewage treatment services. Management of wastewater is worse within secondary cities and wastewater is often directly dumped into rivers, lakes or open fields [8]. Wastewater management priorities in these cities will be different from those in larger cities and developed countries [9]. Limited studies have been conducted on wastewater management within secondary cities in sub-Saharan Africa. Therefore, the current study assesses wastewater management and associated health risks within a secondary city of sub-Saharan Africa.

\section{Materials and Methods}

\subsection{Description of Study Area}

The study was conducted in Dimbokro, the capital city of N'ZiComoe region, in the center of Côte d'Ivoire. Dimbokro has an urban area of approximately 920 ha, and is located within the boundaries of $3.43^{\circ} \mathrm{W}$ and $4.58^{\circ} \mathrm{W}$ and $6.9^{\circ} \mathrm{N}$ and $7.29^{\circ} \mathrm{N}$. The city is built around a main platen where most administrative and social facilities are located. The road network in the city is one of the most developed of Côte d'Ivoire cities. According to INS (2001) [10], the estimated population was 46,708 inhabitants with about 6673 households which are distributed in twelve (12) neighborhoods (Sokouradjan, Dioulakro, Belleville, Komikro, Residentiel, Cité Soghefia, Blaidy, Coulibaly, Koffikro, Zone Economique, Commerce, Langui-Broukro) (Figure 1). The inhabitants are comprised of Baoulé, the main ethnic group, Senoufo, Dioula and ethnicities from bordering countries. The region has a humid tropical climate. The yearly average temperature is $27.5^{\circ} \mathrm{C}$ and rainfall in this region is bimodal (April to July and October to November) and there are also two dry seasons (December to March and August to September). During the rainy seasons, the monthly average rainfall recorded at the Dimbokro station between 1980 and 2002 was $155 \mathrm{~mm}$, the minimum and the maximum rainfall recorded during this period are respectively $100 \mathrm{~mm}$ in July and $200 \mathrm{~mm}$ in June [11]. The vegetation is a mix of lowland rain forest and secondary grassland.

\subsection{Data Collection}

In this study, data were collected using a questionnaire. The questionnaire contained 106 questions, grouped into four sections relating to: socio-demographic, typology of the habitat, water resources and supply, wastewater collection and disposal at household and city level, and associated health risks. The format included both open 


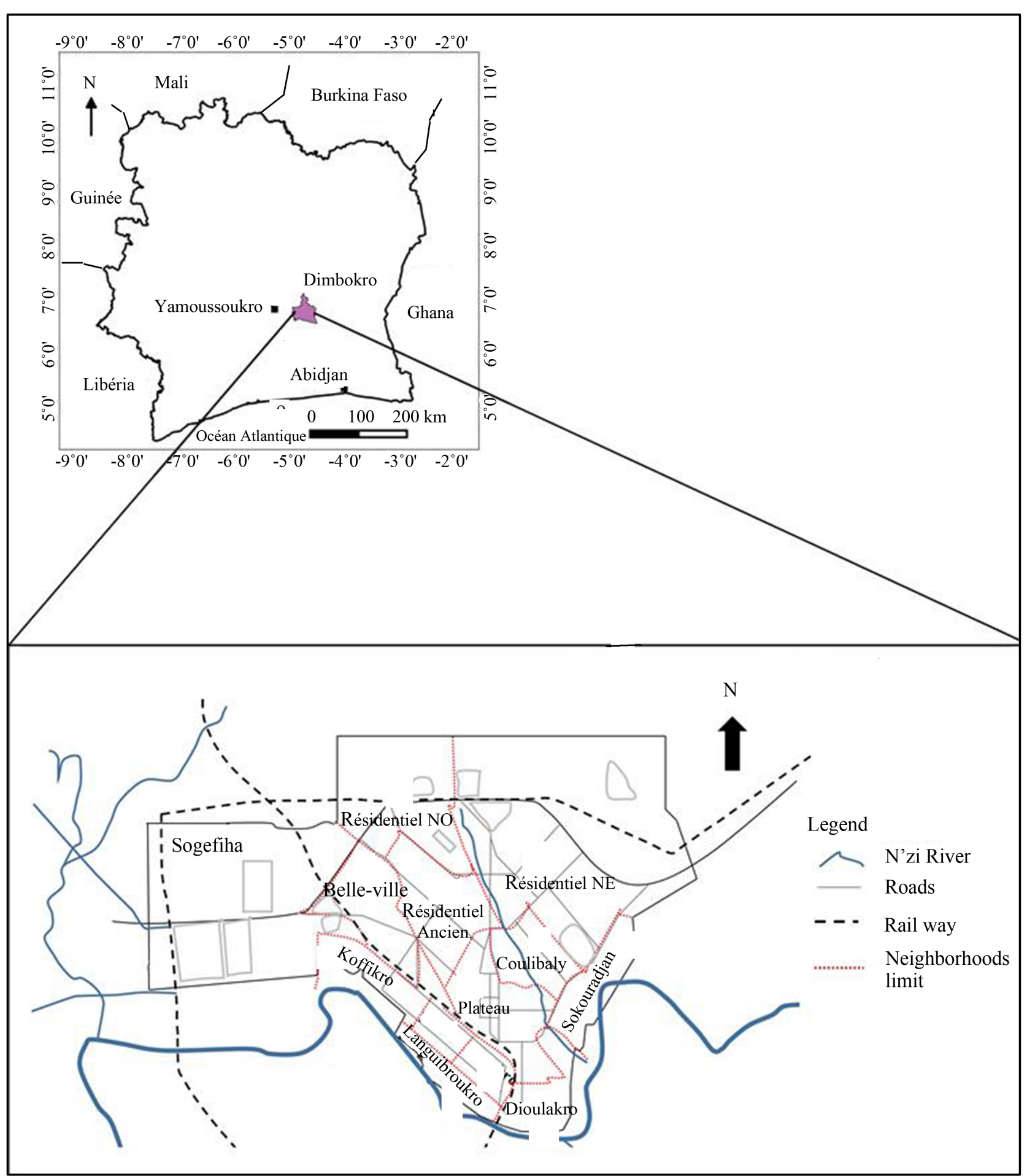

Figure 1. Location of study areas in Dimbokro.

and closed questions. The interviewed respondents were the household heads or any adult in the household level. Each person was subjected to an interview of approximately 20 to $30 \mathrm{~min}$. The survey was conducted by 15 interviewers on March 2015. The languages for the interviews were Baoulé, Malinké or French. The survey was conducted using the quota method and categorization by neighborhood and household number following the method of Fine (2013) [12]. The sample size was calculated by the equation below [13]: 


$$
n=\frac{t^{2} p q N}{\left[e^{2}(N-1)+t^{2} p q\right]}
$$

where:

$n$ : minimum sample size required to obtain meaningful results for an event and the associated level of risk;

$t$ : confidence Level (for a 95\% confidence interval, the typical value of the confidence level is 1.96), it is the probability that the chosen sample have influenced the results obtained;

$N$ : the size of the parent population;

$e$ : margin of error (set to 3.5\%), which expresses the extent to which the results reflect reality at the household level;

$q=1-p, p$ : probability of occurrence of the event, it is the percentage of samples with the observed characteristic; (the probability of occurrence is assumed to be $50 \%(0.5)$ );

According to this formula, the survey should consist of 703 households. The sample distribution per neighborhood is shown in Table 1.

\subsection{Data Analysis}

The responses were standardized and registered in a file; whole percentages were used for data analysis. Then, detail data are analyzed on the basis of the simple tabulation and the cross tabulation of a range of variable. Data analysis was carried out in Microsoft Excel tools. Moreover, the tables and figures were drawn with Excel software.

\section{Results and Discussion}

\subsection{Socio-Demographic Characteristics and Typology of the Habitat for Surveyed Households Acronyms}

The city of Dimbokro is divided into 12 neighborhoods and the survey included 703 households. The household interviews were organized following category of living standards which were linked with the type of housings identified in Dimbokro. These households were structured in three living standards at the twelve neighborhoods or quarters identified. Indeed, the residential, economic and evolutive or yards housing were characterized by the high income, middle class and low income respectively. The study findings about the typology of habitat in the city are represented in Table 2. The study shows that the residential, economic and evolutive housing represented 5\%, $42 \%$ and 53\% respectively. The residential housings are characterized by the walls with cement,

Table 1. Table type styles (Table caption is indispensable).

\begin{tabular}{|c|c|c|c|c|}
\hline Neighborhood & Population & Households & Quotas & Samples \\
\hline Sokouradjan & 10,062 & 1437 & 21.54 & 129 \\
\hline Dioulakro & 6007 & 858 & 12.86 & 90 \\
\hline Belleville & 4569 & 653 & 9.78 & 69 \\
\hline Komikro & 4456 & 637 & 9.54 & 67 \\
\hline Résidentiel & 4449 & 636 & 9.53 & 67 \\
\hline CitéSoghefia & 3603 & 515 & 7.71 & 54 \\
\hline Blaidy & 3343 & 478 & 7.16 & 50 \\
\hline Coulibaly & 3152 & 450 & 6.75 & 47 \\
\hline Koffikro & 2665 & 381 & 5.71 & 40 \\
\hline Zone Economique & 1826 & 261 & 3.91 & 30 \\
\hline Commerce & 1727 & 247 & 3.70 & 30 \\
\hline Langui-Broukro & 849 & 121 & 1.82 & 30 \\
\hline Total & 46,708 & 6673 & 100 & 703 \\
\hline
\end{tabular}


Table 2. Socio-demographic characteristics and typology of the habitat for surveyed households.

\begin{tabular}{ccc}
\hline & Socio Demographic Characteristics & Percentage \\
\hline Typology of Habitat & Residential housings & $5.0 \%$ \\
& Economic housings & $42.0 \%$ \\
Gender of head & Evolutive housings & $53.0 \%$ \\
households & Male & $47.4 \%$ \\
Age of head & Female & $52.6 \%$ \\
households & 25 - 50 years & $63.0 \%$ \\
& 50 - 70 years & $32.2 \%$ \\
Education level \\
of head households & $>70$ years & $4.8 \%$ \\
& High school education & $15.6 \%$ \\
Secondary school education, & $32.1 \%$ \\
Primary school education & $14.8 \%$ \\
households & No formal education & $37.5 \%$ \\
& Practice business & $35.0 \%$ \\
\hline
\end{tabular}

usually painted and the roof sheet. Buildings of economic housings are cement or mud mixed with cement. And the other hand, the evolutive housing has constructed with precarious materials and detached houses. Besides, many economic and evolutive housing was respectively found in residential (58.3\%), Komikro (16.1\%) and Sokouradjan (23.6\%). Several neighborhoods such Dioulakro, Komikro, Belleville, Blaidy and Langui-Broukro do not have any households in the high standard of living category. Similar proportions were reported in Marady, Niger by Laminou Manzo et al. (2015) [3] and in Pouytenga, Burkina Faso by Sawadogo (2009) [14]. Of those surveyed, males comprise $47.4 \%$ of the heads of households, while females comprise $52.6 \%$. More than half of the household head were between 25 - 50 years of age and around $63 \%$ were the household heads. Among the head households, $15.6 \%$ had completed high school education, $32.1 \%$ secondary school education, $14.8 \%$ primary school education, and $37.5 \%$ had no formal education. Among those surveyed, $25.9 \%$ are wage and salary earners, 35\% practice business, $3.4 \%$ are unemployed, $6 \%$ are retired and $29.7 \%$ housewife (Table 2).

\subsection{Water Supply and Uses of Surveyed Households}

In Dimbokro, 99.4\% of households use water from SODECI which is the public water supply network and 0.6\% of households use wells. This percentage is higher than the estimated percentage (82\%) for people using improved drinking water sources in Côte d'Ivoire. This accessibility of populations to water provided by SODECI is due to the efforts of the authorities to promote sanitation, health and development [15]. 82\% of households are connected to water taps and $18 \%$ use an informal distribution system (water vendor and public taps or public drinking fountains). For those using the informal distribution system, water supply for the household is provided mainly by women and children or the single man.

The quantity of water used daily in a household differs from one household to another, depending on household typologies and the size of the household. The mean daily total water supply (TWS) from SODECI ranged from $35 \mathrm{~L}$ to $3178 \mathrm{~L}$. In contrast, the TWS from an informal distribution system linked to the public network of water ranged from $10 \mathrm{~L}$ to $2000 \mathrm{~L}$. The daily highest TWS from SODECI was estimated as $492 \mathrm{~L}$ in economic housing, followed by $341 \mathrm{~L}$ and $330 \mathrm{~L}$ for residential and evolutive housing respectively. The daily water supply cost was estimated respectively as 135 Fcfa (0.23 US\$) and 207 Fcfa (0.36 US\$) for SODECI and informal distribution systems. Similarly, several studies reported that the cost of access to water from informal distribution 
systems is higher than the cost from water taps in the household [16] [17]. Drinking water from the informal distribution systems is stored in containers for future use.

Regarding domestic activities, the results show that $99.7 \%$ and $95.6 \%$ of households use water from SODECI for drinking and cooking respectively, while $0.1 \%$ and $4.4 \%$ use water from wells for the same activities (Figure 2). High quantities of tap water from SODECI are used for showering, laundry and dishwashing. Certain households sometimes use well water for showers (29.2\%), laundry (33\%) dishwashing (29\%) and small-scale gardening $(0.6 \%)$.

\subsection{Domestic Wastewater Collection and Disposal at Household Level}

The main uses of SODECI that lead to large quantities of wastewater are shower, laundry and dishwashing with more than $90 \%$ in residential housing, while economic and evolutive housing generated around $70 \%$ wastewater. Domestic wastewater production in the household depends on the household size and the availability and use of the water.

Most domestic wastewater is discharged directly into the environment. $45 \%$ of surveyed households discharged laundry and dishwashing wastewater directly into the street, $25 \%$ in backyards, while $5.4 \%$ into the sewer network (Figure 3). Similar behavior was observed by Hounpke et al. (2014) [2] and Laminou Manzo et al. (2015) [3]. In Dimbokro, 60\% of inhabitants discharged wastewater very often in the street. However, 59.5\%

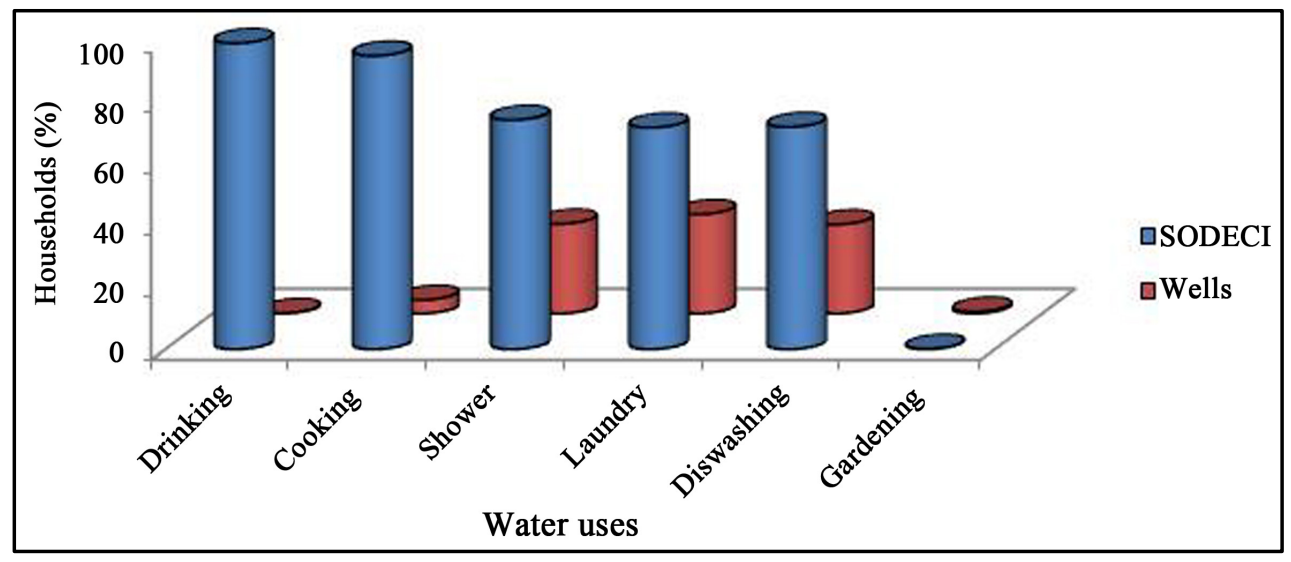

Figure 2. Water uses within surveyed households.

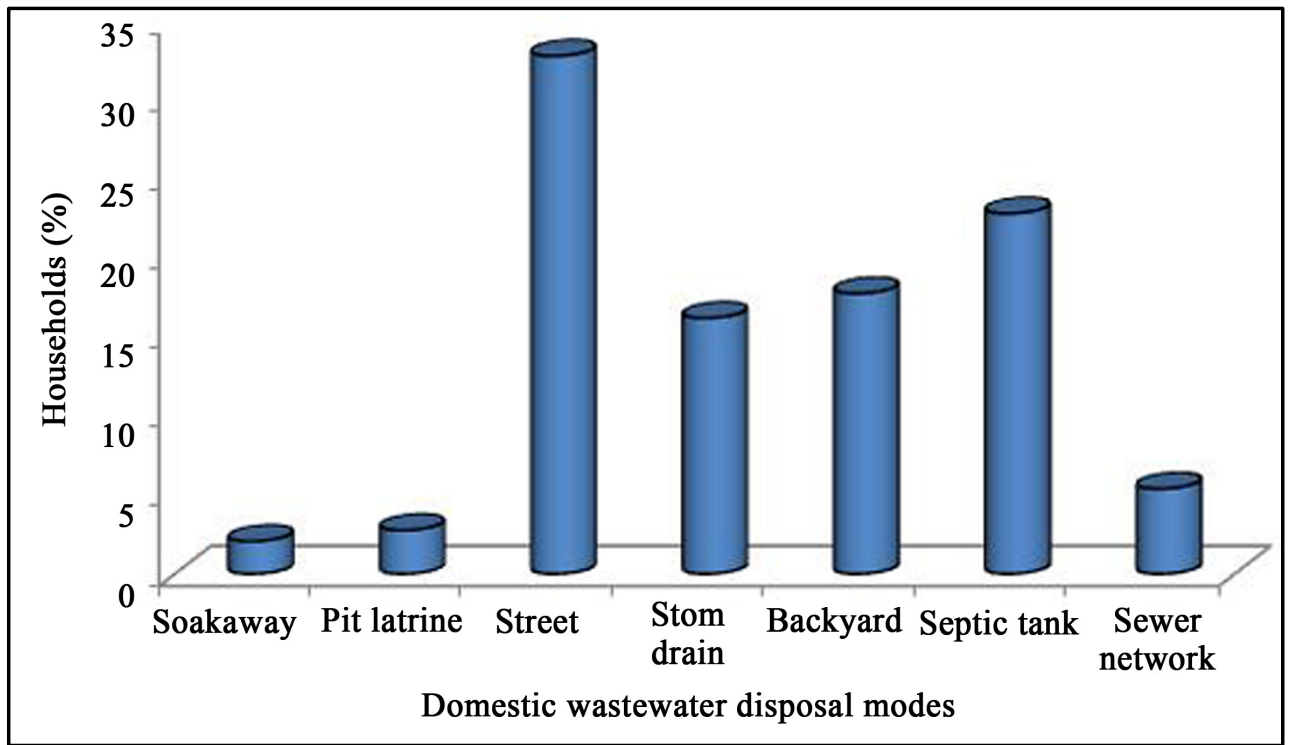

Figure 3. Wastewater collection and disposal in Dimbokro. 
of households used septic tanks for disposal of wastewater from showers, while $3.1 \%$ emptied it to backyards. The domestic wastewater disposal varies depending on the living standard. $68 \%$ of evolutive housing discharged domestic wastewater into the street, compared to $6 \%$ of residential housing. Generally, there are no sewer systems or poorly constructed sewer systems in small cities of sub-Saharan Africa [18]. Inhabitants of evolutive housing do not designate sewage systems, while those in residential housing, $35 \%$, of economic housing and $10 \%$ of evolutive housing use the public storm water drains to dispose of wastewater.

\subsection{Domestic Wastewater Collection and Disposal at City Level}

Dimbokro has a relatively good drainage system and for rainwater and sewer system for wastewater in the center of the city. However, the drainage system is poorly constructed in N'Zi river areas, especially in the Dioulakro and Sokouradjan neighborhoods. The sewer system is composed of open gutters and earth canals, mainly along the primary paved roads. Dimbokro does not have a wastewater system. However, there is a small sanitation canal, which is the main collector of sewage from the city jail and disposes it directly into the N'Zi river without treatment. Any households are also connected to that channel and discharge their untreated wastewater. Private sewage systems are collected to a treatment plant in SOGHEFIA, which is the only structured neighborhood of Dimbokro city. The coverage of private sewage is less than $10 \%$ of the population in Dimbokro. Unfortunately, this wastewater treatment plant is out of use (Figure 4), and municipal authorities have diverted the private sewage with untreated wastewater into the N'Zi river through open channels. This poses serious health risks to the population and the environment. For example, many other cities of East Africa, wastewater is frequently discharged into the Lake Victoria, where the water quality grossly deteriorated [19]. The results showed that the implementation of conventional wastewater collection, treatment and disposal systems is not economically viable as the financial and institutional resources coupled with the efficiency required for their maintenance. Indeed, most sub-Saharan municipalities and cities do not have the means to manage a centralized sewage system [20].

\subsection{Faecal Sludge Management}

The type of sanitary infrastructures used by households on-site is represented in Figure 5. Most households surveyed (56\%) collect sludge in septic tanks, followed by traditional pit latrines (38\%) and the latrine linked to the sewer network (6\%). Faecal sludge disposal varies by standard of living; $97.2 \%$ of residential housings use septic tanks, while $51 \%$ of evolutive housing deposits faecal sludge in traditional pit latrines. Deposition of

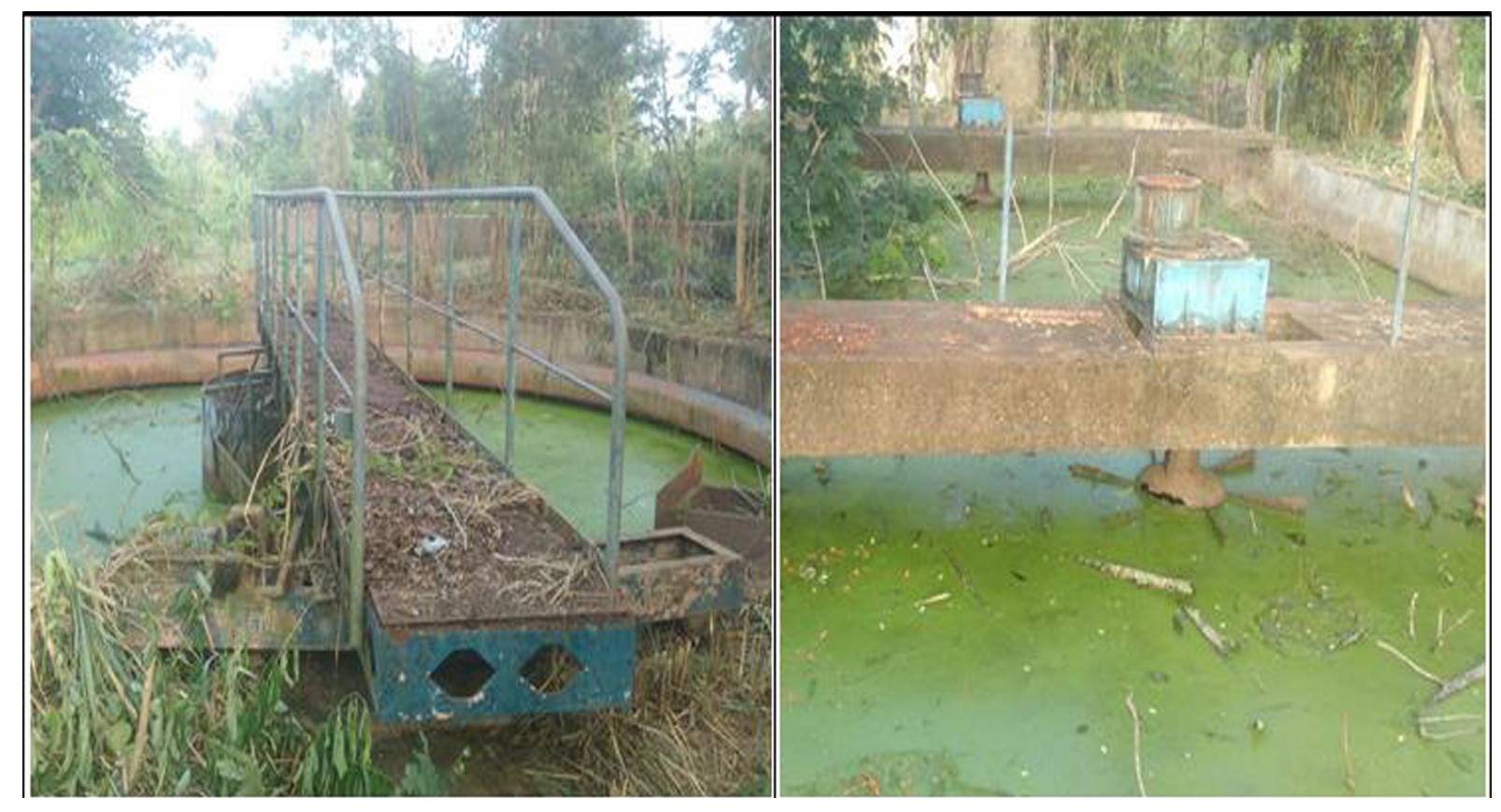

Figure 4. Inoperative wastewater treatment plant. 


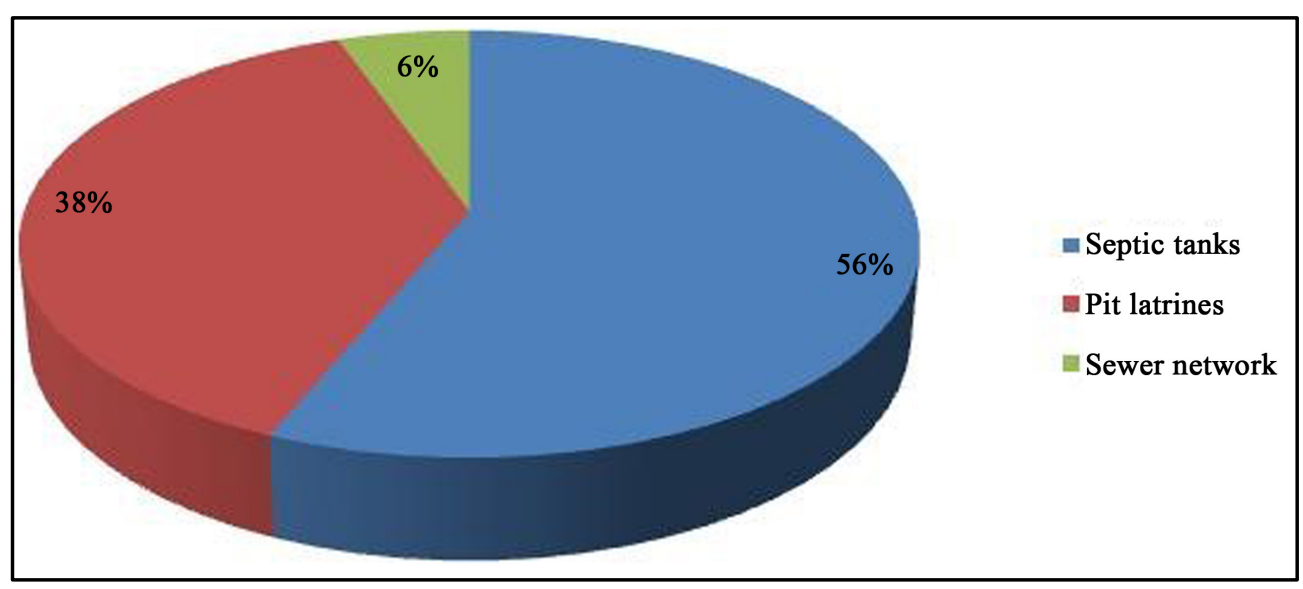

Figure 5. Types of faecal sludge collection in Dimbokro.

excrements near houses is rare. 52\% of households surveyed empty the latrines manually and $48 \%$ used mechanic drain services (Figure 6). In contrast, the proportion of manual and mechanical methods for emptying latrines was $13 \%$ and $87 \%$ respectively in Pouytenga, Burkina Faso [14]. Those living in residential housing (77.8\%) use mechanical drain services such a truck to remove the faecal sludge, while those in evolutive housing (56\%) empty manually. The manual and mechanical emptying latrine or desludging fees were 13,000 and 24,300 Francs cfa (22.46 and 41.98 US\$) respectively. Desludging fees depend on geographical location in the city and the companies negotiate directly with households. According to more than half of the households, high desludging fees determine whether they use manual or mechanical methods. $41 \%$ of households discharged faecal sludge into the street and/or backyard, $6 \%$ into the sewer network and 53\% of households did not know where their faecal sludge ends/goes. Similar studies have reported these faecal sludge management practices in big and small cities of developing countries [2] [14]. Trucks that drain faecal sludge come from major cities to secondary cities. Moreover, Dimbokro does not have a faecal sludge system treatment, which involves the anarchist discharges of the by-products in around of the city. This management is similar in many towns of developing countries and related the health issue for the inhabitants. Despite the health and social problems associated with informal faecal sludge management, it provides significant economic benefits that need to be retained. Indeed, the faecal sludge treated is efficient as biofertilizer supplement or alternative to chemical fertilizers for poor farmers in developing countries [21]. Thereby, the municipalities must integrate the informal sector into faecal sludge management planning, building on their practices and experience.

\subsection{Health Impacts}

In the majority of the surveyed households (62.2\%), the inhabitants experienced disease during six months prior to the study. This situation is noticed in $69.4 \%$ of evolutive housing, while $47.2 \%$ of people in the residential housings are facing illness cases (Figure 7). Similar observations were reported in Marady in Niger [3]. Lowincome households in the evolutive housing live in an unhealthy environment, which are mainly responsible for diseases. Wastewater management is one of many basic strategies for keeping the environment clean and safe for human habitation according to Tumwine et al. (2002) [6].

More children (69.8\%) had diseases than adults (30.2\%) in surveyed households. This could be explained by the poor sanitation in the poorest households and particularly for children in those households. Typical diseases included Malaria (63\%), Diarrhoea (13\%) and Typhoid fever (9\%) (Table 3). Most households (91\%) made a connection between wastewater management practices and health risks. Similar observations were seen in Yaoundé (Cameroon) by Kouam (2013) [22], where significant sections of the population suffer from wastewater related diseases. This could be explained by the problems of blockage of drainage channels leading to stagnant pools of wastewater for mosquito breeding, flies and odors all leading to health hazards. Moreover, waterborne diseases such as Cholera, Malaria, Diarrhoea, Dysentery and Typhoid fever are a permanent fixture within populations in the precarious quarters in Douala [23]. According to Tumwine et al. (2002) [6], higher rates of Diarrhoea were associated with unprotected sources of water and lack of latrines in East Africa. In the light of 


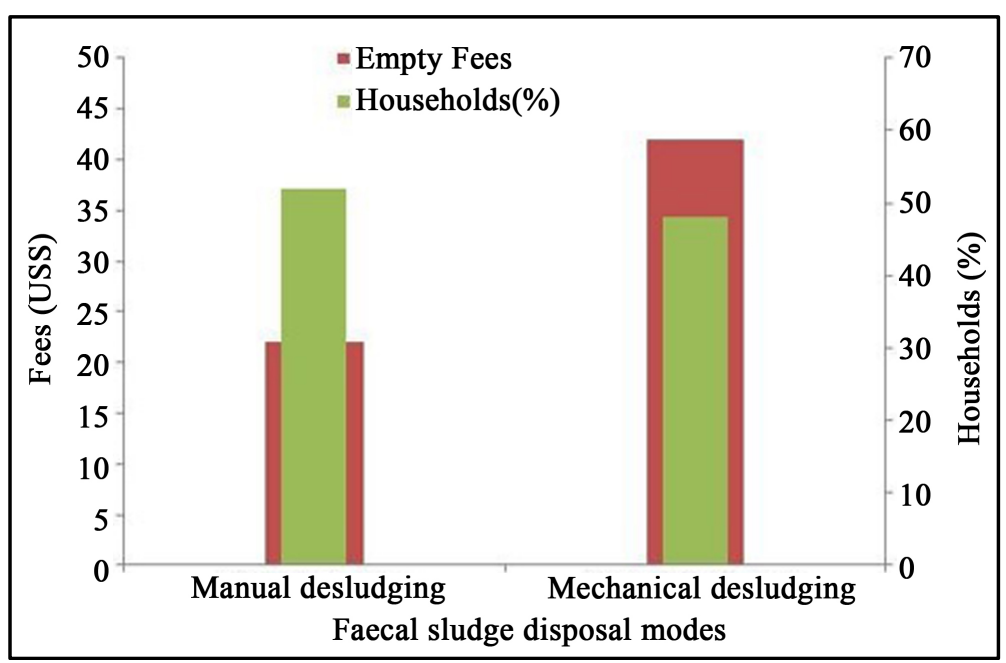

Figure 6. Faecal sludge disposal and cost in Dimbokro.

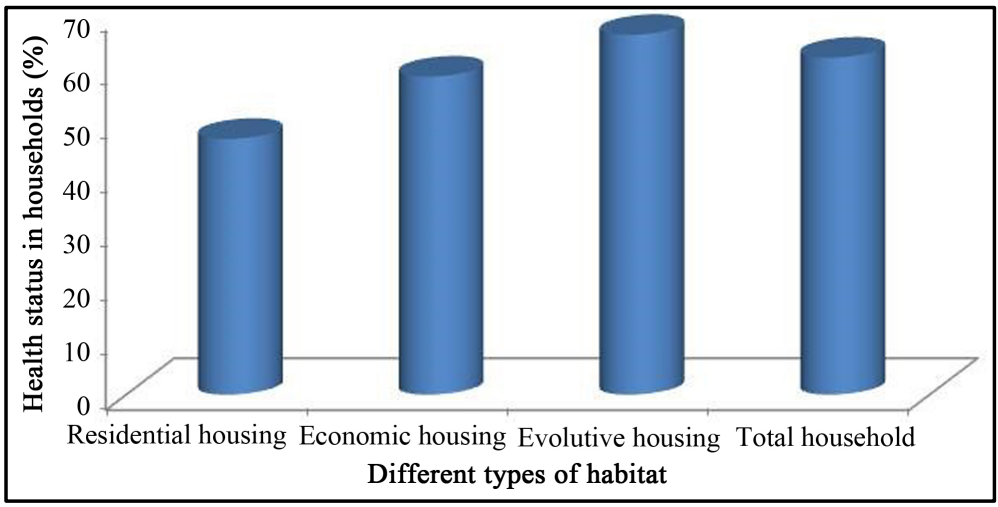

Figure 7. Health status of different housing types in Dimbokro.

Table 3. Mains diseases per adults and children in Dimbokro.

\begin{tabular}{ccc}
\hline & \multicolumn{2}{c}{ Inhabitants of households } \\
\cline { 2 - 3 } & Adults & Children \\
\hline Health status & $30 \%$ & $70 \%$ \\
Malaria & $56.2 \%$ & $69.8 \%$ \\
Diarrhoea & $10.2 \%$ & $18.6 \%$ \\
Typhoid Fever & $8.3 \%$ & $9.1 \%$ \\
Cholera & $0.4 \%$ & $0.3 \%$ \\
\hline
\end{tabular}

these studies, considerable effort should go into the development of improved water supply and sanitation facilities. The survey showed that the majority of respondents became more aware of domestic wastewater management issues, and decided to pay supplementary fees for improving hygiene and sanitation in general. These financial efforts could prevent disease outbreaks and health environment.

\section{Conclusion}

This study interviewed households in Dimbokro, Côte D’Ivoire, to understand socio-demographic characteristics and the wastewater and faecal sludge management. The results showed the sources (SODECI and wells) of the water supply used in the home, prevalence of illness, state and use of latrines, types of wastewater disposal and 
conditions of use. $81.7 \%$ of households are connected to water taps and $18.3 \%$ get water from an informal system of distribution. $68 \%$ of those in evolutive housing discharge their domestic wastewater into the street, compared to $6 \%$ of those in residential housing. However, the sewage from the city jail is discharged directly into the N'Zi river without treatment. There is a predominance of Malaria (63\%) which affects more children (69.8\%) than adults (56.2\%). Globally, the current study notes the high utilization of autonomous systems of sanitation and faecal sludge management, which are typical in larger and secondary cities of developing countries. The results also show that improper wastewater management in Dimbokro constitutes a serious hazard to humans as well as the environment. It would be significant for the authorities to increase levels of investment in water supply and sanitation facilities in secondary cities of developing countries. In addition, these authorities must multiply the public awareness campaigns of the populations to hygiene and healthiness programs for improvements of the environmental health benefits and facilitate the construction of basic improved sanitation facilities for the poorest households based on joint efforts with the community. Government should provide drainages in the secondary cities and restore wastewater treatment plant according to the population size.

\section{Acknowledgements}

The authors would like to thank Miss Katherine Lownsbery (University of Massachusetts, Amherst, United States of America) for providing comments on the English and content of this paper.

\section{References}

[1] WHO/UNICEF (2014) Progress on Sanitation and Drinking-Water-2014 Update. WHO Press, World Health Organization, Geneva, 75 p.

[2] Hounkpe, S.P., Adjovi, C.E., Crapper, M. and Esi, A. (2014) Wastewater Management in Third World Cities: Case Study of Cotonou, Benin. Journal of Environmental Protection, 5, 387-399. http://dx.doi.org/10.4236/jep.2014.55042

[3] Laminou Manzo, O., Saidou, H., Abdourahamane Illiassou, S. and Tidjani Idrissa, S. (2015) Assessment of Domestic Wastewater Management Practices in the Communal District I of Maradi City, Niger Republic. Journal of Geoscience and Environment Protection, 3, 57-65. http://dx.doi.org/10.4236/gep.2015.38006

[4] Mbéguéré, M., Gning, J., Dodane, P. and Koné, D. (2010) Socio-Economic Profile and Profitability of Faecal Sludge Emptying Companies. Resources, Conservation and Recycling, 54, 1288-1295. http://dx.doi.org/10.1016/j.resconrec.2010.04.008

[5] Evans, B. (2005) Securing Sanitation: The Compelling Case to Address the Crisis. Stockholm International Water Institute (SIWI), 48. http://www.who.int/water_sanitation_health/hygiene/securingsanitation.pdf

[6] Tumwine, K.J., Thompson, J., Katua-Katua, M., Mujwajuzi, M., Johnstone, N., Wood, E. and Porras, I. (2002) Diarrhoea and Effects of Different Water Sources, Sanitation and Hygiene Behaviour in East Africa. Tropical Medicine and International Health, 7, 750-756. http://dx.doi.org/10.1046/j.1365-3156.2002.00927.x

[7] Abrams, L. (2001) Water for Basic Needs. Commissioned by the World Health Organization as Input to the 1st World Water Development Report. http://www.thewaterpage.com/coverage_figures.htm

[8] Kamyotra, J.S. and Bhardwaj, R.M. (2011) Municipal Wastewater Management in India. India Infrastructure Report, 299-311.

[9] Verbyla, E.M., Oakley, M.S. and Mihelcic, R.J. (2013) Wastewater Infrastructure for Small Cities in an Urbanizing World: Integrating Protection of Human Health and the Environment with Resource Recovery and Food Security. Environmental Science \&Technology, 47, 3598-3605. http://dx.doi.org/10.1021/es3050955

[10] Institut National de la Statistique (INS) (2001) Recensement Général de la Population et de l’Habitat (RGPH) 1998. Données sociodémographiques et économiques des localités, résultats définitifs par localité, région du N’ziComoe, Vol. III, tome 1, 43 p.

[11] Koita, M. (2010) Caractérisation et modélisation du fonctionnement hydrodynamique d’un aquifère fracturé en zone de socle. Région de Dimbokro-Bongouanou (Centre Est de la Côte d’Ivoire). Thèse de Doctorat, Université Montpellier II, Montpellier, $220 \mathrm{p}$.

[12] Fine, J. (2013) Pour plus de transparence sur la méthodologie des sondages électoraux. Statistique et société, Société Française de Statistique, 1, 23-29. www.statistique-et-societe.fr

[13] Tuffery, S. (2012) Data mining et statistique décisionnelle. Edition Technip, 4e Edition, L'intelligence des données, $848 \mathrm{p}$.

[14] Sawadogo, A. (2009) Etat des lieux détaillé de l’assainissement environnemental de la ville de Pouytenga-Burkina 
Faso. Master d’Ingénierie de l'Eau et de l'Environnement, Institut International d’Ingénierie de l'Eau et de l'Environnement (2iE), Ouagadougou, 60 p.

[15] Coulibaly, L., Diomandé, D., Coulibaly, A. and Gourène, G. (2005) Utilisation des ressources en eaux, assainissement et risques sanitaires dans les quartiers précaires de la commune de Port-Bouët (Abidjan; Côte d’Ivoire). VertigO, 5, 111. http://vertigo.revues.org/3299

[16] Dos Santos, S. (2005) Koom la viim: Enjeux socio-sanitaires de la quête de l'eau à Ouagadougou (Burkina Faso). Thèse de Doctorat de Démographie, Université de Montréal, Montréal, 182 p.

[17] Koukougnon, W.G. (2015) Stratégies d'accès à l'eau potable dans un quartier défavorisé: cas de Gobelet dans la commune de Cocody (Abidjan-Côte d'Ivoire). Canadian Journal of Tropical Geography, 2, 60-72. http://laurentienne.ca/rcgt

[18] Kagu, A., Badawi, L.H. and Abba, J.M. (2013) Assessment of Domestic Wastewater Disposal in Some Selected Wards of Maiduguri Metropolis, Borno State, Nigeria. Journal of Geography and Geology, 5, 83-93. http://dx.doi.org/10.5539/jgg.v5n4p83

[19] Kansiime, F., Saunders, J.M. and Loiselle, A.S. (2007) Functioning and Dynamics of Wetland Vegetation of Lake Victoria: An Overview. Wetlands Ecological Management, 15, 443-451. http://dx.doi.org/10.1007/s11273-007-9043-9

[20] Bateganya, L.N., Nakalanzi, D., Babu, M. and Hein, T. (2015) Buffering Municipal Wastewater Pollution Using Urban Wetlands in Sub-Saharan Africa: A Case of Masaka Municipality, Uganda. Environmental Technology, 36, 2149-2160. http://dx.doi.org/10.1080/09593330.2015.1023363

[21] Koné, D. and Strauss, M. (2004) Performances et Challenges des Techniques de traitement à faible coût (rustiques) des Boues de Vidange. Présenté au Forum de recherche en eau et assainissement, CREPA, Ouagadougou, 6-10 déc.

[22] Kouam Kenmogne, G.-R. (2013) Vers une gestion rationnelle de l'eau dans une situation complexe d'urbanisation anarchique dans un pays en développement: cas du bassin versant de l'Abiergue (Yaounde-Cameroun). Thèse de Doctorat, Département des Sciences et Gestion de l'Environnement d’Arlon, Université de Lièges, Belgique, 223 p.

[23] Ndjama, J., KamgangKabeyene, B.V., Sigha Nkamdjou, L., Ekodeck, G. and Awah, M.T. (2008) Water Supply, Sanitation and Health Risks in Douala, Cameroon. African Journal of Environmental Science and Technology, 2, 422-429.

\section{Submit or recommend next manuscript to SCIRP and we will provide best service for you:}

Accepting pre-submission inquiries through Email, Facebook, LinkedIn, Twitter, etc.

A wide selection of journals (inclusive of 9 subjects, more than 200 journals)

Providing 24-hour high-quality service

User-friendly online submission system

Fair and swift peer-review system

Efficient typesetting and proofreading procedure

Display of the result of downloads and visits, as well as the number of cited articles

Maximum dissemination of your research work

Submit your manuscript at: http://papersubmission.scirp.org/ 